
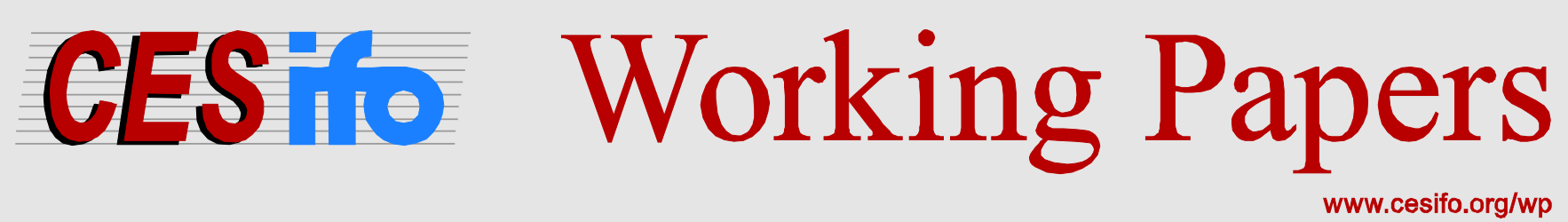

\title{
Transportation Costs and the Great Divergence
}

\author{
Leonid V. Azarnert
}

\author{
CESIFO WORKING PAPER NO. 4766 \\ CATEgory 6: Fiscal Policy, Macroeconomics and Growth \\ APRIL 2014
}
An electronic version of the paper may be downloaded
- from the SSRN website:
- from the RePEc website:
- from the CESifo website:
WwW.SSRN.com
Www.RePEc.org
www.CESifo-group.org/wp

\section{CESifo}




\title{
Transportation Costs and the Great Divergence
}

\begin{abstract}
This work shows the asymmetric effect of the reduction in transportation costs across different sectors in the process of the Great Divergence. Specifically, the analysis indicates that reductions in transportation costs of industrial goods enhance convergence of the growth rates of trading economies. In contrast, reductions in transportation costs of non-industrial goods contribute to a further divergence across countries.
\end{abstract}

JEL-Code: F110, F430, J100, N300, O400.

Keywords: international trade, trade costs, transportation revolution, fertility, economic growth.

Leonid V. Azarnert

Department of Economics and Business Administration

Ariel University

Israel - Ariel, 40700

Leonid.Azarnert@gmail.com

I am grateful to Oded Galor, Andrew Mountford and two anonymous referees whose comments broadened considerably the scope of the paper and helped improve the presentation of the results. 


\section{Introduction}

Recent years have witnessed a significant increase in the interest in the "Great Divergence" in income per capita across countries in the course of the last two centuries. Thus, for example, the ratio between income per capita in the richest region of the world and the poorest region of the world has increased from a modest about 3 to 1 in the beginning of the $19^{\text {th }}$ century to about 20 to 1 in the beginning of the $21^{\text {st }}$ century. Similarly, during the same period, the ratio between income per capita in Western Europe and Asia grew nearly threefold. At the same time, while the West has excelled in the growth of income per capita, other regions have been dominant in population growth. To explain this historical pattern, several studies pointed to a considerable increase in international trade during this period and suggested that trade had an asymmetrical effect on the evolution of industrial and non-industrial economies, enhancing growth in the former and impeding growth in the latter (see Galor and Mountford (2006, 2008) and Galor (2011) for details, evidence and further references).

Rapid expansion of trade and the divergence of incomes across the globe also coincided with a gradual decline in trade costs. Thus, for instance, Bairoch (1989) estimates that the transport cost as percentage of production costs for a 800 kilometer trade shipment of manufactured iron goods was 27 percent in 1830, 21 percent in 1850,10 percent in 1880, and 6 percent in 1910. Similarly, real ocean freight rates fell by nearly $35 \%$ from 1870 to 1910 (Clark and Feenstra, 2003). In the $20^{\text {th }}$ century, transportation costs continued to decrease further. In particular, oceanic shipping costs declined by about 70 percent from 1920 to 1960 and airfreight rates declined by about 80 percent from 1930 to 1980 (see, for example, Baldwin, Martin and Ottaviano (2001), where further evidence and references can also be found).

Furthermore, and more important in the context of the present work, transportation improvements were not symmetric across sectors and periods. Thus, initially, when transportation costs were very high, trade was almost entirely concentrated in luxury goods. Later on, in the course of the $18^{\text {th }}$ century sharp declines in the costs of transportation led to the rapid expansion of trade in manufactured goods. Thereafter, from the beginning of the $19^{\text {th }}$ century, an increase in the speed of maritime transportation significantly expanded trade in expensive agricultural goods, such as, for example, coffee, tea, and tobacco with a later addition 
of the opium trade with China. From the mid-century on, further declines in the cost of transportation stimulated an additional increase in the volume of industrial trade. Similarly, they made possible a further diversification of agricultural trade toward cheaper tropical groceries, such as sugar, vegetable oils and some fruits, which led to a dramatic increase in the tonnage of tropical groceries imported into Europe (Bairoch, 1995). Henceforth, in the course on the $20^{\text {th }}$ century, transportation improvements became less important for the industrial sector, since the transport cost as percentage of production costs was already relatively low (Bairoch, 1995), while increased shipping speed was not a very important factor for transportation of industrial goods. At the same time, in the agricultural sector declining shipping costs along with an increase in the speed of transportation expanded international trade toward the cheapest staple foods and fruits, while further technological improvements made transportation of frozen foods possible. ${ }^{1}$

This work examines the role that reductions in transportation costs played in the process of the Great Divergence. The analysis is performed in the context of a growth model with two goods, two countries and endogenous fertility building on Galor and Mountford (2006, 2008) who argued that international trade reinforced the initial comparative advantages of trading economies and generated a persistent effect on the distribution of the world population and hence a great divergence in incomes per capita across countries and regions. ${ }^{2}$

The present work expands the analysis toward the costs of trade, from which Galor and Mountford abstract. The present analysis demonstrates that a decline in transportation costs of different internationally traded goods has an asymmetric effect on the growth rates of trading economies. Thus, a reduction in transportation costs of industrial, skilled-labor intensive, good enhances growth of the less advanced economy and thereby induces convergence of the growth rates of the trading economies. In contrast, a reduction in transportation costs of non-industrial, unskilledlabor intensive, good slows down growth of the less advanced economy and thus contributes to a further divergence across the countries.

\footnotetext{
${ }^{1}$ A detailed description of the intercontinental trade since the Industrial Revolution with a particular emphasis on the Third World and references can be found, for instance, in O'Brien (1997). For a detailed survey of recent trends in trade costs see Anderson and van Wincoop (2004).

${ }^{2}$ For a survey of a recent literature on endogenous fertility and growth, see Galor (2005; 2012); cf. also Galor (2011) and Azarnert (2009; 2010).
} 
The effect of the reduction in transportation costs, and the associated expansion in trade, on geographically based industrialization and global divergence was recently analyzed in several studies. However, these studies, such as, for instance, Krugman and Venables (1995) and Baldwin, Martin and Ottaviano (2001), focused only on the reduction in the transportation costs of the skilled-labor intensive, industrial, goods and, for simplicity, assumed that the unskilled-labor intensive, traditional, goods can be traded costlessly. The present work expands this literature in the direction of the reduction in the costs for trade in the traditional, agricultural, goods that can affect the world economy asymmetrically. ${ }^{3}$

Further on, in a more general setting, this work's results can also be applicable to the evaluation of the recent reductions in trade barriers imposed in developed economies on unskilled-labor intensive agricultural imports from presently developing countries. Thus, for example, in the early 1990s, under the Uruguay Round Agreement on Agriculture, developed countries reduced their tariffs on agricultural products by $37 \%$ on average, whilst the average reduction in tariffs on tropical products, which are of particular interest for developing countries, was $43 \%$ (Hanson and Loader, 2001). Later on, following the 2000 Millennium Summit, developed economies further lowered their tariff barriers imposed on agricultural imports from developing countries (World Bank, 2010). The intuition presented in this paper allows us to suggest that the current trend of reductions in agricultural trade barriers may not necessarily be growth enhancing for developing countries. ${ }^{4}$

The remainder of the article is organized as follows. Section 2 presents the basic framework following closely the original setup of Galor and Mountford (2006, 2008). Section 3 presents and analyzes the role of the declines in the transportation costs in the process of the Great Divergence, which is the major contribution of the present work. Section 4 concludes.

\footnotetext{
${ }^{3}$ Ashraf, Galor and Ozak (2010) argue that economies that were geographically isolated (i.e., in the context of the present paper economies with higher transportation costs) benefited from their isolation, suggesting perhaps that they avoided the adverse effect of past globalization on the development of presently less developed countries.

${ }^{4}$ Neto (in press) suggests that, if human capital is nontradable, convergence in open economies will be slower than in closed economies. Bond, Iwasa and Nishimura (2013) show that, if the labor-intensive good is inferior, trade can pull an initially rich country into powerty. Yuki (2008) suggests that the shift of production, employment and consumption from the traditional sector to the modern sector is a source of development. Finally, Imrohoroglu, Imrohoroglu and Ungor (in press) identify low productivity growth in the agricultural sector as the main source for the divergence of income per capita between Turkey and its peer countries between 1968 and 2005. Cf. also Azarnert (2014).
} 


\section{The Basic Structure of the Model}

Following Galor and Mountford (2006, 2008), I consider a world consisting of two perfectly competitive overlapping-generations economies that are identical in every respect except that economy $A$ is more technologically advanced than $B$. In each period $t$, in every country $j=A, B$, two goods, an industrial good, $Y_{t}^{m, j}$, and an agricultural good, $Y_{t}^{a, j}$, may be produced using up to two factors of production: skilled labor $H_{t}^{j}$, and unskilled labor $L_{t}^{j}$. The size of the adult population, $N_{t}^{j}$, and its decomposition between skilled and unskilled workers evolve endogenously over time.

\subsection{Production}

In country $j=A, B$, the traditional agricultural good can be produced with the unskilled labor only. The output of the agricultural good produced in period $t, Y_{t}^{a, j}$, is

$$
Y_{t}^{a, j}=A^{a, j} L_{t}^{a, j},
$$

where $A^{a, j}$ is the level of productivity of agricultural technology, which is fixed over time in both countries, and $L_{t}^{a, j}$ is the level of employment of unskilled labor in the agricultural sector in period $t$.

The production of the more advanced industrial good requires both unskilled and skilled labor. The output of the industrial good produced in period $t, Y_{t}^{m, j}$, is

$$
Y_{t}^{m, j}=A_{t}^{m, j}\left(H_{t}^{j}\right)^{\gamma}\left(L_{t}^{m, j}\right)^{1-\gamma}=A_{t}^{m, j} L_{t}^{m, j}\left(h_{t}^{m, j}\right)^{\gamma},
$$

where $A_{t}^{m, j}$ is the level of productivity of industrial technology in period $t$, which is higher in more technologically advanced economy $A ; \forall t, A_{t}^{m, A}>A_{t}^{m, B} . L_{t}^{m, j}$ and $H_{t}^{j}$ are the levels of employment of unskilled and skilled labor in the industrial sector in the corresponding period, with the relative employment of skilled labor in this sector $h_{t}^{m, j} \equiv H_{t}^{j} / L_{t}^{m, j}$.

In anticipation of international trade, the following assumption ensures that the technologically advanced economy $A$ has a comparative advantage in the production of the industrial good: 
A1: $\quad \forall t, \frac{A_{t}^{m, A}}{A^{a, A}}>\frac{A_{t}^{m, B}}{A^{a, B}}$

As in Galor and Mountford (2006), I suppose that in the industrial sector technological progress is possible and that the rate of technological progress between periods $t$ and $t+1, \quad g_{t+1}^{j}$, is affected positively by the skill abundance, i.e., the proportion of skilled individuals in the entire labor force, $h_{t}^{j} \equiv H_{t}^{j} /(\alpha+\beta) N_{t}^{j}$, in period $t:^{5}$

$$
g_{t+1}^{j} \equiv \frac{A_{t+1}^{m, j}-A_{t}^{m, j}}{A_{t}^{m, j}}=g\left(h_{t}^{j}\right),
$$

where $g\left(h_{t}^{j}\right)$ is a positive, increasing concave function; $\forall h_{t}^{j}>0, g\left(h_{t}^{j}\right)>0$, $g^{\prime}\left(h_{t}^{j}\right)>0, \quad g^{\prime \prime}\left(h_{t}^{j}\right)<0$.

Producers operate in perfectly competitive markets for final goods and for labor. As long as both goods are produced, from equations (1) and (2), the inverse demand for unskilled labor in the agricultural sector is

$$
w_{t}^{u, j}=p_{t}^{j} A^{a, j},
$$

the inverse demand for unskilled labor in the industrial sector is

$$
w_{t}^{u, j}=(1-\gamma) A_{t}^{m, j}\left(h_{t}^{m, j}\right)^{\gamma},
$$

and the inverse demand for skilled labor is

$$
w_{t}^{s, j}=\gamma A_{t}^{m, j}\left(h_{t}^{m, j}\right)^{\gamma-1},
$$

where $w_{t}^{u, j}$ and $w_{t}^{s, j}$ are the wages of unskilled and skilled workers, and $p_{t}^{j}$ is the relative price of the agricultural good in terms of the industrial good in period $t$, while the price of the industrial good is normalized to one.

Since unskilled workers are perfectly mobile between the agricultural and the industrial sectors, the wages of unskilled labor in both sectors are equal if both goods are produced. Therefore, as follows from equations (4) and (5), the relative price of the agricultural good in terms of the industrial good, $p_{t}^{j}$, is

$$
p_{t}^{j}=(1-\gamma)\left(h_{t}^{m, j}\right)^{\gamma}\left(A_{t}^{m, j} / A^{a, j}\right) .
$$

\subsection{Individuals}

\footnotetext{
${ }^{5}$ Technological progress in the agricultural sector will not affect the qualitative results as long as it is slower than that in the industrial sector. See Galor and Mountford (2008) for more details.
} 
Individuals live for two periods. In their first period of life, agents are children: each child consumes a fixed fraction of his parent's time, while educated offspring requires a larger fraction of parental time. In their second period of life, individuals become adults. As adults, they are endowed with one unit of time, as either skilled $(s)$, or unskilled $(u)$ workers, which they allocate between labor force participation and child rearing. As parents, they choose both the number and quality of their offspring.

An adult $i$ from country $j=A, B$ in period $t$ derives utility from the consumption of the agricultural good, $c_{t}^{i, a, j}$, the consumption of the industrial good, $c_{t}^{i, m, j}$, and the total future income of his children: ${ }^{6}$

$$
U_{t}^{i, j}=\alpha \ln c_{t}^{i, a, j}+\beta \ln c_{t}^{i, m, j}+(1-\alpha-\beta) \ln \left(w_{t+1}^{s, j} n_{t}^{i, s, j}+w_{t+1}^{u, j} n_{t}^{i, u, j}\right),
$$

where $n_{t}^{i, s, j}$ and $n_{t}^{i, u, j}$ are the numbers of children trained to be skilled and unskilled workers, and $w_{t+1}^{u, j}$ and $w_{t+1}^{s, j}$ are their wages in period $t+1$.

The budget constraint of an adult $i$ (skilled or unskilled) in period $t$ is

$$
p_{t}^{j} c_{t}^{i, a, j}+c_{t}^{i, m, j}+w_{t+1}^{i, j}\left(n_{t}^{i, s, j} \tau^{s}+n_{t}^{i, u, j} \tau^{u}\right) \leq w_{t}^{i, j},
$$

where $\tau^{s}$ and $\tau^{u}$ is the time required to raise skilled and unskilled offspring, respectively; $\tau^{s}>\tau^{u}$.

Given the homotheticity of the utility function, the optimal consumption of each of the goods and the time devoted to child rearing have constant budget shares.

The consumption of the agricultural good by an individual $i$ from country $j$ in period $t$ is therefore

$$
c_{t}^{i, a, j}=\alpha w_{t}^{i, j} / p_{t}^{j},
$$

while the consumption of the industrial good is

$$
c_{t}^{i, m, j}=\beta w_{t}^{i, j} .
$$

The number of educated and uneducated offspring will be determined such that the aggregate time devoted in period $t$ by an individual $i$ from country $j$ to child rearing is

$$
n_{t}^{i, s, j} \tau^{s}+n_{t}^{i, u, j} \tau^{u}=1-\alpha-\beta
$$

\footnotetext{
${ }^{6}$ I abstract here from child mortality, which is analyzed, for example, in Azarnert (2006) and references therein.
} 
where $\left\{\begin{array}{llll}n_{t}^{i, u, j}>0 & \text { and } n_{t}^{i, s, j}=0, & \text { if } & w_{t+1}^{s, j} / w_{t+1}^{u, j}<\tau^{s} / \tau^{u} \\ n_{t}^{i, u, j}>0 & \text { and } n_{t}^{i, s, j}>0, & \text { if } & w_{t+1}^{s, j} / w_{t+1}^{u, j}=\tau^{s} / \tau^{u} \\ n_{t}^{i, s, j}>0 & \text { and } n_{t}^{i, u, j}=0, & \text { if } & w_{t+1}^{s, j} / w_{t+1}^{u, j}>\tau^{s} / \tau^{u}\end{array}\right.$

\subsection{The Autarkic Equilibrium}

In autarky, since both goods are desired by consumers, they are produced. The demand for skilled and unskilled labor is strictly positive and therefore $w_{t+1}^{s, j} / w_{t+1}^{u, j}=\tau^{s} / \tau^{u}$. Hence, the ratio of skilled and unskilled labor employed in the industrial sector is unique and constant over time:

$$
H_{t}^{j} / L_{t}^{m, j}=\gamma \tau^{u} /(1-\gamma) \tau^{s} \equiv \hat{h}^{m} .
$$

The employments of unskilled labor in each of the two sectors, $L_{t}^{a, j}=\alpha L_{t}^{j} /[(1-\gamma)+\alpha \gamma /(\alpha+\beta)], \quad$ and $L_{t}^{m, j}=\beta L_{t}^{j} /[1+\alpha \gamma /(1-\gamma)(\alpha+\beta)]$, are fixed fractions of the number of unskilled workers in that period, $L_{t}^{j}$. Since $H_{t}^{j}=L_{t}^{m, j} \hat{h}^{m}$, the employment of skilled labor is a fixed fraction of $L_{t}^{j}$ as well. Moreover, the skilled abundance in the entire labor force, $h_{t}^{j} \equiv H_{t}^{j} /(\alpha+\beta) N_{t}^{j}$, is constant over time. The autarkic economy is thus in a state of a balanced growth with constant rates of growth of technology, population and income per capita.

On this balanced growth path, the autarkic relative price of the agricultural good, $p_{t}^{j}=(1-\gamma)\left(\hat{h}^{m}\right)^{\gamma}\left(A_{t}^{m, j} / A^{a, j}\right)$ increases over time due to technological progress in the industrial sector. Since technological advancement is biased towards the industrial sector and, given assumption A1, $\forall t,\left(A_{t}^{m, A} / A^{a, A}\right)>\left(A_{t}^{m, B} / A^{a, B}\right)$, the autarkic relative price of the agricultural good in the technologically advanced economy $A$ is always higher, than that in economy $B$, i.e., $\forall t, p_{t}^{A}>p_{t}^{B}$.

\subsection{International Trade}

For international trade between the two countries to be established, the international equilibrium relative price of the agricultural good, $p_{t}^{*}$, should be determined in between the autarkic equilibrium prices of the two economies: $p_{t}^{B} \leq p_{t}^{*} \leq p_{t}^{A}$. 
Therefore, when trade is established, from the viewpoint of the technologically advanced economy $A$, there is a reduction in the relative price of the agricultural good, which induces an increase in the production of the skilled-labor intensive industrial good at the expense of a reduction in the production of the agricultural good. In contrast, from the viewpoint of the less advanced economy $B$ there is an increase in the relative price of the agricultural good, which induces an increase in the production of the unskilled-labor intensive agricultural good at the expense of a reduction in the production of the industrial good.

Moreover, since $\forall t, \quad p_{t}^{A}>p_{t}^{B}$, when trade is established, at least one of the economies completely specializes in the production of either agricultural, or industrial good. Furthermore, if $p_{t}^{B}<p_{t}^{*}<p_{t}^{A}$, both economies completely specialize: the more technologically advanced economy $A$ produces and exports the industrial good and the less advanced economy produces and exports the agricultural good.

If economy $A$ completely specializes in the production of the industrial good, an increase in the demand for skilled workers reduces fertility in this economy to

$$
n^{A^{*}}=(1-\alpha-\beta)\left(1-\gamma\left(1-\tau^{u} / \tau^{s}\right)\right) / \tau^{u} .
$$

The skill abundance in economy $A$ thus rises to

$$
h^{A^{*}}=\hat{h}^{m} .
$$

If economy $B$ completely specializes in the production of the agricultural good, this completely eliminates the demand for skilled workers. As a result, fertility rate in economy $B$ rises to

$$
n^{B^{*}}=(1-\alpha-\beta) / \tau^{u}
$$

and its skilled intensity decreases to

$$
h^{B^{*}}=0 .
$$

As a result, since technological progress is a positive function of the skill abundance in the economy, international trade increases the rate of technological progress in economy $A$ and decreases the rate of technological progress in economy $B$ relative to autarky. Furthermore, when specialization is incomplete and the economy remains diversified, the effect of international trade on the rate of technological progress is higher the higher is the degree of specialization.

\section{Transportation Costs}


Proceeding now to the major theme of the present work, in Section 3.1, I first introduce the definition of the transportation costs. Then, I compute the international equilibrium relative price of the agricultural good, if both economies completely specialize, as presented and analyzed in Galor and Mountford (2006). Next, in Section 3.2, I discuss the effect of the changes in the transportation costs on the rates of growth of the two economies. Further on, in Section 3.3, I extend the analysis toward the incomplete specialization in trading economies and analyze the effect of the technological progress in transportation on the evolution of the world economy in the long run.

\subsection{International Equilibrium Price}

To deal with the costs of trade, I adopt the standard iceberg transportation costs, which however can be different for agricultural and industrial goods. Specifically, I suppose that in any period $t$, in presence of any non-negative costs of transportation only a fraction $S_{t}^{a} \quad\left(0<S_{t}^{a, \min } \leq S_{t}^{a} \leq 1\right)$ of the exported agricultural good and, similarly, only a fraction $S_{t}^{m}\left(0<S_{t}^{m, \min } \leq S_{t}^{m} \leq 1\right)$ of the exported industrial good, arrives in the other country.

With such definition of the transportation costs, the rate of technological progress in transportation between two periods $t$ and $t+1$ is

$$
s_{t+1}^{\sigma} \equiv \frac{S_{t+1}^{\sigma}-S_{t}^{\sigma}}{S_{t}^{\sigma}}, \quad \sigma=a, m .
$$

With trade, if $p_{t}^{B}<p_{t}^{*}<p_{t}^{A}$, the technologically advanced economy $A$ specializes in the production of the industrial good, producing $(\alpha+\beta)\left(\hat{h}^{m}\right)^{\gamma} A_{t}^{m, A} L_{t}^{A}$ and exporting $\alpha\left(\hat{h}^{m}\right)^{\gamma} A_{t}^{m, A} L_{t}^{A}$ units of the good. Economy $B$ specializes in the production of the agricultural good, producing $(\alpha+\beta) A^{a, B} L_{t}^{B}$ and exporting $\beta A^{a, B} L_{t}^{B}$ units of the good. With any non-negative transportation costs, $S_{t}^{m} \leq 1$ and $S_{t}^{a} \leq 1$, only a fraction $S_{t}^{m} \alpha\left(\hat{h}^{m}\right)^{\gamma} A_{t}^{m, A} L_{t}^{A}$ of the industrial export of economy $A$ arrives in economy $B$ and, similarly, only a fraction $S_{t}^{a} \beta A^{a, B} L_{t}^{B}$ of the agricultural export of economy $B$ arrives in economy $A$.

The balanced trade condition requires that 


$$
p_{t}^{*} S_{t}^{a} \beta A^{a, B} L_{t}^{B}=S_{t}^{m} \alpha\left(\hat{h}^{m}\right)^{\gamma} A_{t}^{m, A} L_{t}^{A} .
$$

The international equilibrium price of the agricultural good in terms of the industrial good is therefore:

$$
p_{t}^{*}=\frac{S_{t}^{m} \alpha\left(\hat{h}^{m}\right)^{\gamma} A_{t}^{m, A} L_{t}^{A}}{S_{t}^{a} \beta A^{a, B} L_{t}^{B}} .
$$

Eq. (20) demonstrates that a reduction in the transportation costs of the agricultural good, as captured by an increase in $S_{t}^{a}$, reduces the international relative price of the agricultural product $\left(p_{t}^{*}\right)$, whilst a reduction in the transportation costs of the industrial good, as captured by an increase in $S_{t}^{m}$, increases that price. ${ }^{7}$

\subsection{Economic Growth Rates}

By construction of this model, from homotheticity of the utility function (4) follows that changes in the transportation costs do not affect the total amounts of goods produced in the world. Given that the price of the industrial good is assumed to be a numeraire, transportation costs also do not affect the value of the output of economy $A$ if that economy specializes in the industrial good:

$$
Y_{t}^{m, A}(\alpha+\beta)\left(\hat{h}^{m}\right)^{\gamma} A_{t}^{m, A} L_{t}^{A} .
$$

However, through their effect on the international equilibrium relative price of the agricultural good, as specified in Eq. (20), changes in the transportation costs affect the relative value of the output of economy $B$ that produces agriculture: ${ }^{8}$

$$
p_{t}^{*} Y_{t}^{a, B}=(\alpha+\beta)\left(\hat{h}^{m}\right)^{\gamma} A_{t}^{m, A} L_{t}^{A} \frac{\alpha S_{t}^{m}}{\beta S_{t}^{a}}
$$

\footnotetext{
${ }^{7}$ In other words, transportation improvements in the agricultural sector generate a positive terms of trade effect for economy $A$ that imports agriculture and a negative terms of trade effect for economy $B$ that exports it, while the opposite is true for transportation improvements in the industrial sector. In addition, from Eq. (20) it is also evident that a decrease in transportation costs of the industrial good, or an increase in the transportation costs of the agricultural good, has analytically the same effect as an improvement in the production technology of the industrial good. This implies that Proposition 1 and Corollary 1 of Galor and Mountford (2006) still apply.

${ }^{8}$ Under alternative formulation, if the price of the agricultural good is assumed to be a numeraire, changes in transportation costs would affect the world economy through their effect on the value of the output of economy $A$, while leaving the value of the output of economy $B$ unaffected. In this case, reductions in transportation costs of industrial good would reduce the relative value of the output and, hence, the rate of growth of economy $A$, thus closing the gap between the trading economies. In contrast, reductions in transportation costs of the agricultural good would work in the opposite direction, thus leading to a further divergence across the countries. Therefore, the qualitative nature of the effect of the reductions in the transportation costs of different products on the nature of the Great Divergence would remain unaltered.
} 
Moreover, Eq. (22) shows the asymmetric effect of the changes in the transportation costs of different products. While a reduction in the transportation costs of the industrial good positively affects the relative value of the output of the less advanced economy $B$, a reduction in the transportation costs of the agricultural good affects it negatively.

Now, since the value of the industrial output of economy $A$ (Eq. 21) does not depend on the transportation costs, its growth rate, $G_{Y, t+1}^{A}$ :

$$
G_{Y, t}^{A}=n^{A^{*}}\left(1+g\left(h^{A^{*}}\right)\right)-1,
$$

as well as the growth rate per capita:

$$
g_{Y, t}^{A}=g\left(h^{A^{*}}\right),
$$

are not affected by the changes in the transportation costs.

In contrast, changes in the transportation costs between period $t$ and $t+1$, or, in other words, the rate of technological progress in transportation $\left(s_{t+1}^{\sigma}\right)$, affect the growth rate of the total value of the output of economy $B$ (Eq. 22):

$$
G_{Y, t}^{B}=\frac{1+s_{t}^{m}}{1+s_{t}^{a}} n^{A^{*}}\left(1+g\left(h^{A^{*}}\right)\right)-1
$$

and, hence, with $n^{A^{*}}$ and $n^{B^{*}}$, as given in (14) and (16) respectively, the growth rate per capita in economy $B$ :

$$
g_{Y, t}^{B}=\frac{1+s_{t}^{m}}{1+s_{t}^{a}}\left(1-\gamma\left(1-\frac{\tau^{u}}{\tau^{s}}\right)\right)\left(1+g\left(h^{A^{*}}\right)\right)-1 .
$$

Moreover, the effect of the decline in transportation costs on the growth rates of economy $B$ is also asymmetric: positive in case of the skilled-labor intensive industrial product and negative in the case of the non-industrial, agricultural product; $\frac{d G_{Y, t}^{B}}{d s_{t}^{m}}>0$ and $\frac{d g_{Y, t}^{B}}{d s_{t}^{m}}>0$, while $\frac{d G_{Y, t}^{B}}{d s_{t}^{a}}<0$ and $\frac{d g_{Y, t+1}^{B}}{d s_{t}^{a}}<0$.

\subsection{The Evolution of the World Economy}

International trade is preferable to autarky for both economies as long as $p_{t}^{B} \leq p_{t}^{*} \leq p_{t}^{A}$. Therefore, once transportation costs decline enough to make trade 
mutually worthwhile, ${ }^{9}$ the world economy can evolve through the following three stages: From Stage 1 of incomplete specialization in economy $A$ along with complete specialization in economy $B$ via Stage 2 of complete specialization in both economies to Stage 3 of incomplete specialization in economy $B$ along with complete specialization in economy $A .^{10}$

\subsubsection{Stage 1: Incomplete specialization in economy $A$ and complete specialization}

in the agricultural good in economy $B ; p_{t}^{B}<p_{t}^{*}=p_{t}^{A}$

With comparative advantages as specified in assumption A1, $\forall t, p_{t}^{B}<p_{t}^{A}$. Therefore, once trade becomes viable, if economy $B$ is not too large relative to economy $A,{ }^{11}$ while, at the same time, the degree of specialization in economy $A$ is not too high, the international equilibrium price of the agricultural good can initially be determined such that $p_{t}^{B}<p_{t}^{*}=p_{t}^{A}$.

If the international price is determined in such a manner, as long as $p_{t}^{B}<p_{t}^{*}$, the less technologically advanced economy $B$ completely specializes in the production of the unskilled-labor intensive agricultural good. As a consequence, its fertility rate rises, skilled intensity declines, and the human capital accumulation and technological progress decline relative to autarky, as shown in Section 2.4.

At the same time, as long as $p_{t}^{A}=p_{t}^{*}$, the more technologically advanced economy $A$ remains diversified. This equality can be maintained as long as the combined world demand for the industrial good is insufficient to absorb the total possible output of that good in economy $A$, even at the lowest international price (i.e., when the mirror relative price of the agricultural good that economy $B$ exports is the highest, as determined by the autarkic price in economy $A ; p_{t}^{*}=p_{t}^{A}$ ). Furthermore, a decline in the transportation cost of the industrial good increases the amount of the imported industrial good that arrives in economy $B$, which further

${ }^{9}$ Trivially, trade is not worthwhile for both economies if the cost of transportation of both goods is too high. In addition, if the cost of transportation of the agricultural good is very high, as captured by a low $S_{t}^{a}$, whereas the cost of transportation of the industrial good is relatively low, as captured by a high $S_{t}^{m}$, trade will be desirable for economy $B$ and not worthwhile for economy $A$. Similarly, if the cost of transportation of the industrial good is relatively high and the cost of transportation of the agricultural good is low, trade will be worthwhile only for economy $A$.

${ }^{10}$ The reverse case, when the world starts off with economy $B$ incompletely specialized and economy $A$ completely specialized, follows trivially using the same intuition.

${ }^{11}$ If economy $B$ is large enough relative to economy $A$, the world economy would immediately proceed to Stage 2, or Stage 3. 
reduces the foreign demand for that good. In contrast, a decline in the transportation cost of the agricultural good increases the amount of the imported agricultural good that arrives in economy $A$, which induces a reduction of its own agricultural production. Therefore, transportation improvements in the agricultural sector act to stimulate transition from agriculture to industry in economy $A$, whereas transportation improvements in the industrial sector act to impede that transition.

Clearly, as in the case of the complete specialization, international trade causes an increase in the production of the skilled-labor intensive industrial good in economy $A$ at the expense of a reduction in the production of agricultural good. The ratio of skilled workers in this economy increases to $h_{t}^{A}$, thereby increasing the rate of technological progress, although as long as specialization is incomplete, this ratio is still lower than $h^{A^{*}}$, as shown in Eq. (15). Since the production of skilled children requires more time, the rate of fertility in economy $A$ declines to

$$
n_{t}^{B}=\frac{1-\alpha-\beta}{\tau^{u}+\left(\tau^{s}-\tau^{u}\right) h_{t}^{A}},
$$

although it is still higher than under complete specialization; $n_{t}^{A}>n^{A^{*}}$.

Hence, the growth rate per capita in economy $A$ rises to $g_{Y, t}^{A}=g\left(h_{t}^{A}\right)$, although growth in economy $A$ is also still slower than under complete specialization; $\forall h_{t}^{A}<h^{A^{*}}, g\left(h_{t}^{A}\right)<g\left(h^{A^{*}}\right)$.

This allows us to conclude that as long as economy $A$ remains diversified, technological progress in transportation in the agricultural sector increases the degree of specialization of economy $A$ in the production of the industrial good, thus increasing the amount of human capital accumulation and then the rate of technological progress and economic growth per capita. In contrast, technological progress in transportation in the industrial sector decreases the degree of specialization of economy $A$ in the production of the industrial good, thus decreasing the amount of human capital accumulation and then the rate of technological progress and economic growth per capita.

Recall that with trade economic growth in a less developed economy $B$ depends on that in economy $A$. Therefore, with $n_{t}^{A}$ and $n_{t}^{B}$, as given in (27) and (16) respectively, the growth rate per capita in economy $B$ is 


$$
g_{Y, t}^{B}=\frac{1+s_{t}^{m}}{1+s_{t}^{a}}\left(1+\left(\tau^{s}-\tau^{u}\right) h_{t}^{A}\right)^{-1}\left(1+g\left(h_{t}^{A}\right)\right)-1 .
$$

Therefore, as Eq. (28) demonstrates, under complete specialization in economy $B$ and incomplete specialization in economy $A$ the effect of the bias in technological progress in transportation on the per-capita economic growth in economy $B$ is similar to that under complete specialization in both economies. Notice also that, while the per-capita growth rate in economy $A, g_{Y, t}^{A}=g\left(h_{t}^{A}\right)$, affects $g_{Y, t+1}^{B}$ positively, a reduction in population growth in economy $A$, as follows from an increase in the share of skilled labor in its workforce, $h_{t}^{A}$, weakens this positive effect.

On this growth path, putting aside the asymmetric effect of transportation improvements in different sectors, the worldwide supply of the agricultural good tends to increase, as follows from an increase in the relative size of economy $B$ owing to its higher reproduction rate. As the supply of the agricultural good increases enough, the relative international price of agriculture will ultimately decline below the high autarkic level in economy $A ; p_{t}^{*}<p_{t}^{A}$. From this period on, economy $A$ becomes completely specialized and the world economy proceeds to Stage 2 .

\subsubsection{Stage 2: Complete specialization in the industrial good in economy $A$ and} complete specialization in the agricultural good in economy $B ; p_{t}^{B}<p_{t}^{*}<p_{t}^{A}$ At this stage, the economies evolve along the growth path with fertility rates, skilled intensity, technological progress, and the growth rates, as described previously in Sections 2.4 to 3.2 .

Complete specialization in production will be maintained as long as $p_{t}^{B}<p_{t}^{*}<p_{t}^{A}$, i.e., as long as

$$
(1-\gamma) \frac{A_{t}^{m, B}}{A^{a, B}}<\frac{S_{t}^{m} \alpha A_{t}^{m, A} L_{t}^{A}}{S_{t}^{a} \beta A^{a, B} L_{t}^{B}}<(1-\gamma) \frac{A_{t}^{m, A}}{A^{a, A}} .
$$

Hence, economy $B$ will diversify its production once the left inequality is violated, whereas economy $A$ would diversify its production if the right inequality is violated.

Since $n^{B^{*}}>n^{A^{*}}, L_{t}^{A} / L_{t}^{B}$ declines over time. Therefore, if the rate of transportation in the industrial sector is not too fast relative to that in the agricultural 
sector, the right inequality cannot be violated and economy $A$ remains completely specialized. $^{12}$

However, if population growth in economy $B$ is sufficiently large, the amount of the agricultural good exported by economy $B$ will rise over time relative to the amount of the industrial good exported by economy $A$. As a consequence, the relative price of agriculture, $p_{t}^{*}$ will gradually decline. ${ }^{13}$ Once $p_{t}^{*}$ declines sufficiently to reach $p_{t}^{B}$, the left inequality turns into equality $\left(p_{t}^{B}=p_{t}^{*}\right)$. From this period on, economy $B$ becomes diversified and the world economy proceeds to Stage 3 .

On this path, technological progress in transportation of the agricultural good contributes to the decline of $p_{t}^{*}$ and thereby accelerates the transition of economy $B$ to diversification. In contrast, technological progress in transportation of the industrial good slows down the decline of $p_{t}^{*}$ and thereby works in the opposite direction.

\subsubsection{Stage 3: Complete specialization in the industrial good in economy $A$ and} incomplete specialization in economy $B ; p_{t}^{B}=p_{t}^{*}<p_{t}^{A}$

At Stage 3, when the share of economy $B$ in the world economy rises enough, the output of the manufactured good in economy $A$ becomes insufficient to meet the world demand, and economy $B$ becomes diversified in production. Once economy $B$ becomes diversified, as follows from an increase in the demand for skilled labor, its fertility rate declines to

$$
n_{t}^{B}=\frac{1-\alpha-\beta}{\tau^{u}+\left(\tau^{s}-\tau^{u}\right) h_{t}^{B}},
$$

skilled intensity in its workforce rises to $h_{t}^{B}$, and the rate of technological progress rises to $g\left(h_{t}^{B}\right)$.

With a higher rate of technological progress and a lower rate of fertility, the per-capita rate of economic growth in economy $B$ rise to

$$
g_{Y, t}^{B}=\frac{1+s_{t}^{m}}{1+s_{t}^{a}}\left(1-\gamma\left(1-\frac{\tau^{u}}{\tau^{s}}\right)\right)\left(1+\left(\frac{\tau^{s}}{\tau^{u}}-1\right) h_{t}^{B}\right)\left(1+g\left(h^{A^{*}}\right)\right)-1 .
$$

\footnotetext{
${ }^{12}$ Formally, $p_{t}^{*}$ does not approach $p_{t}^{A}$ from below as long as $\left(1+s_{t}^{m}\right) /\left(1+s_{t}^{a}\right) \leq\left(n^{B^{*}} / n^{A^{*}}\right)$.

${ }^{13}$ A necessary and sufficient condition for $p_{t}^{*}$ to decline is $n^{B^{*}}>\left(\left(1+s_{t}^{m}\right)\left(1+g\left(h^{A^{*}}\right)\right) n^{A^{*}}\right) /\left(1+s_{t}^{a}\right)$.
} 
Therefore, as under complete specialization in both economies (Eq. 26) along with incomplete specialization in economy $A$ (Eq. 28), under incomplete specialization in economy $B$, the effect of technological progress in transportation on the per-capita economic growth in economy $B$ is also asymmetric: positive in case of the industrial product and negative in the case of the agricultural product; $\frac{d g_{Y, t}^{B}}{d s_{t}^{m}}>0$, while $\frac{d g_{Y, t}^{B}}{d s_{t}^{a}}<0$. Moreover, under incomplete specialization in economy $B$, the effect is stronger, the lower is the degree of specialization in economy $B$ (i.e., the higher is $h_{t}^{B}$ ).

This allows us to conclude that at all three stages, under complete or incomplete specialization in either economy, transportation improvements in the agricultural sector increase the divergence of incomes per capita across countries, while the opposite is true for transportation improvements in the industrial sector.

Finally, from Eq. (31) it is also clear that the lower is the degree of specialization in the agricultural product in economy $B$, the higher is its per-capita growth rate. ${ }^{14}$ At the same time, in completely specialized economy $A$ the rate of growth per capita is fixed at $g_{Y, t}^{A}=g\left(h^{A^{*}}\right)$. As a consequence, once economy $B$ becomes diversified, the divergence of the rates of per-capita income growth across the countries begins to decline.

\section{Conclusion}

This work examines the role of the reduction in transportation costs across different sectors in the process of the Great Divergence of incomes per capita across the globe. The analysis is performed in the context of a growth model with two goods, two countries and endogenous fertility, as originally developed by Galor and Mountford (2006, 2008). The analysis shows that, under complete or incomplete specification in either country, a reduction in transportation costs of the skilled-labor intensive industrial good enhances growth of the less advanced economy and thereby induces convergence of the growth rates of the two trading economies. In contrast, a reduction

\footnotetext{
${ }^{14}$ When $h_{t}^{B}=0$, economy $B$ is completely specialized, so that its growth rate, as shown in Eq. (31), is the same as that in Eq. (26).
} 
in transportation costs of the non-industrial, unskilled-labor intensive agricultural good slows down growth of the less advanced economy and thus contributes to a further divergence across the countries.

\section{References}

Anderson, James E. and Eric van Wincoop (2004) Trade Costs. Journal of Economic Literature 42, 691-751.

Ashraf, Quamrul, Oded Galor and Omer Ozak (2010) Isolation and development. Journal of European Economic Association 8, 401-412.

Azarnert, Leonid V. (2006) Child mortality, fertility and human capital accumulation. Journal of Population Economics 19, 285-297.

Azarnert, Leonid V. (2009) Abortion and human capital accumulation: a contribution to the understanding of the gender gap in education. Scottish Journal of Political Economy 56, 559-579.

Azarnert, Leonid V. 2010. Free education, fertility and human capital accumulation. Journal of Population Economics 23, 449-468.

Azarnert, Leonid V. 2014. Transportation Costs and the Great Divergence. Macroeconomic Dynamics (Forthcoming).

Baldwin, Richard E., Martin, Philipp and Gianmarco I.P. Ottaviano (2001) Global income divergence, trade and industrialization: the geography of growth take-off. Journal of Economic Growth 6, 5-37.

Bairoch, Paul (1989) European trade policy, 1815 - 1914. In Peter Mathias and Sidney Pollard (eds.) The Cambridge Economic History of Europe. Cambridge: Cambridge University Press, Vol. 8, pp. 1-160.

Bairoch, Paul. 1995. Economics and the World Trade: Myths and Paradoxes Chicago: University of Chicago Press.

Bond, Eric W., Kazumichi Iwasa and Kazuo Nishimura (2013) Poverty traps and inferior goods in a dynamic Heckcher - Ohlin model. Macroeconomic Dynamics $17,1227-1251$.

Clark, Gregory and Robert C. Feenstra (2003) Technology in the Great Divergence. In Michael D. Bordo, Alan M. Taylor and Jeffrey G. Williamson (eds.) Globalization in Historical Perspective. NBER: University of Chicago Press, pp. 277-313. 
Galor, Oded (2005) From stagnation to growth: unified growth theory. In Aghion Philippe and Steven N. Durlauf (eds.) Handbook of Economic Growth, North Holland, Amsterdam: Elsevier, Vol. 1A, pp. 171-295.

Galor, Oded (2011) Unified Growth Theory. Princeton University Press.

Galor, Oded (2012) The demographic transition: causes and consequences. Cleometrica 6, 1-28.

Galor, Oded and Andrew Mountford (2006) Trade and the Great Divergence: the family connection. American Economic Review 96, 229-303.

Galor, Oded and Andrew Mountford (2008) Trading population for productivity: Theory and evidence. Review of Economic Studies 75, 1143-1179.

Henson, Spencer and Rupert Loader (2001) Barriers to agricultural exports from developing countries: the role of sanitary and phytosanitary requirement. World Development 29, 85-102.

Imrohoroglu, Ayse, Selahattin Imrohoroglu and Murat Ungor (in press) Agricultural productivity and growth in Turkey. Macroeconomic Dynamics.

Krugman, Paul and Anthony J. Venables (1995) Globalization and the inequality of nations. Quarterly Economic Review 110, 857-880.

Neto, Delfim Gomes (in press) Financial globalization and economic growth. Macroeconomic Dynamics.

O'Brien, Patrick Karl (1997) Intercontinental trade and the development of the Third World since the Industrial Revolution. Journal of World History 8, 75-133.

World Bank, 2010. World Development Indicators, Washington, DC: World Bank.

Yuki, Kazuhiro (2008) Sectoral shift, wealth distribution, and development. Macroeconomic Dynamics 12, 527-559. 